\title{
Multiplication of Toxoplasma gondii in Maturing Erythroid Cells
}

\author{
By KAZUYUKI TANABE, ${ }^{\dagger}$ ISAO KIMATA AND \\ SUEHISA TAKADA \\ Department of Medical Zoology, Osaka City University Medical School, \\ Asahi-machi, Abeno-ku, Osaka 545, Japan
}

(Received 14 August 1979; revised 17 October 1979)

\begin{abstract}
Multiplication of Toxoplasma gondii was examined in vitro in murine erythroid cells at different stages of development. Toxoplasma gondii multiplied in nucleated erythroblasts and enucleated reticulocytes from the foetal liver, and in immature reticulocytes and yolk-sac derived erythrocytes from the foetal circulation. However, the rate of multiplication was lowered as erythroblasts matured, and multiplication was not detected in foetal erythrocytes. A decrease in the multiplication rate with maturation was also observed with yolk-sac erythrocytes.
\end{abstract}

\section{INTRODUCTION}

Toxoplasma gondii is a protozoan parasite causing human and animal toxoplasmosis. It contains all organelles commonly seen in eukaryotic cells, but cannot multiply extracellularly. The mechanism which renders it an obligatory intracellular parasite is not known. Culture conditions, such as temperature or the serum concentration in the medium (Lund et al., 1963), and substances released from toxoplasma-immune lymphocytes (Jones et al., 1975; Borges \& Johnson, 1975) have been shown to modulate Toxoplasma multiplication in the host cells. However, little is known about the metabolic aspects of host cell dependency of the parasite. This may be due primarily to the fact that various antimetabolites widely used to analyse the specific mechanism of intracellular parasitism of viruses or chlamydia (Becker, 1973) cannot be applied to the $T$. gondii-host cell system, because they affect both the parasite and its host cell. On the other hand, it is well known that erythroid cells undergo metabolic and structural changes in the course of development, during which they sequentially cease to synthesize DNA, RNA and protein (Marks \& Kovach, 1966; Lowy, 1977) and lose nuclei, mitochondria, endoplasmic reticulum and other organelles (Fantoni et al., 1968; Lessin \& Bessis, 1977). Thus, erythroid differentiation offers a useful experimental system in which to determine to what extent $T$. gondii depends on host cell metabolic activities or which organelles are essential for $T$. gondii multiplication. Previously, we demonstrated that $T$. gondii can penetrate murine erythroid cells at all stages of differentiation and maturation except mature erythrocytes of adult mice (Tanabe et al., 1979). In the present study, $T$. gondii multiplication has been examined in vitro in erythroid cells obtained from the liver and peripheral blood of foetal mice.

$\dagger$ Present address: Radiobiology Division, Tufts - New England Medical Center, 171 Harrison Avenue, Boston, Massachusetts 02111, U.S.A. 


\section{METHODS}

Parasites. Tachyzoites of the RH strain of Toxoplasma gondii were freed from host cells according to the method of Tanabe et al. (1978).

Animals and preparation of erythroid cells. C57B1/ $6 \mathrm{HeMs}$ mice were used. The methods of mating and of preparing erythroid cells from the liver and the peripheral blood on various days of gestation were as described by Tanabe et al. (1979).

Assay for T. gondii multiplication in erythroid cells. Erythroid cell suspensions $\left[0.1 \mathrm{ml}\right.$, containing $5 \times 10^{7}$ cells $\mathrm{ml}^{-1}$ in Eagle's minimum essential medium (MEM, Gibco)] were mixed with $1.9 \mathrm{ml}$ MEM with $15 \%$ $(\mathrm{v} / \mathrm{v})$ foetal calf serum (Gibco) and transferred to Falcon plastic dishes $(35 \times 10 \mathrm{~mm})$. Toxoplasma gondii tachyzoites $\left(10^{7}\right.$ in $0.1 \mathrm{ml}$ MEM) were then inoculated into the cultures; cell smears were made after 4,8 and $24 \mathrm{~h}$ incubation $\left(37^{\circ} \mathrm{C}\right.$, in $5 \% \mathrm{CO}_{2} / 95 \%$ air) and stained with Giemsa stain. The parasites which had multiplied in host cell vacuoles were counted in over 1000 host cells and the results were expressed as the percentage of divided parasites per total number of parasites within the host cells.

\section{RESULTS}

Toxoplasma gondii multiplication was examined on Giemsa-stained cell smears after incubation with erythroid cells from the liver on days 12 to 14 of gestation, when there were few non-erythroid cells (Tarbutt \& Cole, 1970). It was found that $T$. gondii multiplied in all varieties of erythroid cells, i.e. proerythroblasts, basophilic and late (poly- and orthochromatophilic) erythroblasts and nucleated liver reticulocytes (Fig. 1a). The multiplication rate at $8 \mathrm{~h}$ was slightly lower in the reticulocytes than in basophilic or late erythroblasts (Table 1 ). Multiplication was less frequent at $4 \mathrm{~h}$. Since enucleation of late erythroblasts is known to take about $10 \mathrm{~min}$ (Lessin \& Bessis, 1977), some divided parasites found in reticulocytes were probably those which had originally multiplied in late erythroblasts which had expelled their nuclei soon afterwards. The actual rate of multiplication in reticulocytes (Table 1) must therefore be a little lower. Most liver erythroid cells had degenerated by $24 \mathrm{~h}$ after incubation so that no counts were made at this time.

Toxoplasma gondii multiplication was also examined in red blood cells from the foetal circulation, in which two types of erythrocytes are present, i.e. yolk-sac derived nucleated erythrocytes and liver derived non-nucleated erythrocytes (Marks \& Kovach, 1966). The former are known to proliferate and continue to develop as a relatively homogeneous population, whereas the latter start to accumulate and mature in the circulation from day 12 of gestation. The rate of parasite multiplication at 8 and $24 \mathrm{~h}$ in nucleated erythrocytes (Fig. $1 b$ ) was high in those from $11 \mathrm{~d}$ embryos, and thereafter gradually decreased with development (Table 2).

The multiplication rate in non-nucleated erythrocytes also decreased with maturation (Table 2). However, $T$. gondii still divided in non-nucleated erythrocytes from day 15 , when divided parasites were not detected in yolk-sac erythrocytes. Examination of Giemsastained non-nucleated erythrocytes containing divided parasites showed that $95 \%$ of the total divided parasites were in polychromatophilic erythrocytes (PCE), indicating that multiplication had occurred in immature reticulocytes but not in erythrocytes. Remains of divided parasites $(5 \%)$ seen in orthochromatophilic erythrocytes (OCE) may be those which had originally divided in PCE and later shifted to OCE. Toxoplasma gondii appeared not to have multiplied but degenerated in OCE, since degeneration of the parasite in foetal erythrocytes with no ribosomes was observed by electron microscopy (Tanabe et al., 1979). Thus, these results show that $T$. gondii can multiply in liver erythroid cells at all stages of development up to the immature reticulocyte stage (but not in erythrocytes) and in yolk-sac erythrocytes, and that the rate of multiplication decreased with the maturation of both late erythroblasts (into reticulocytes) and yolk-sac erythrocytes. 

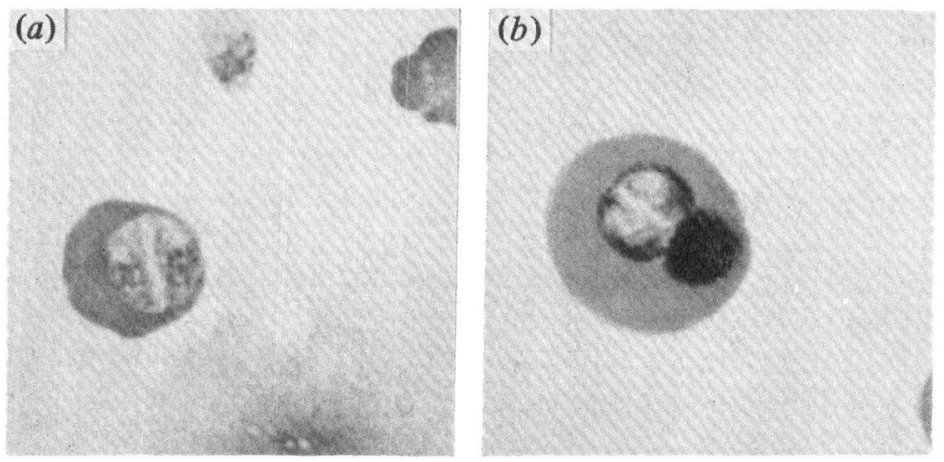

Fig. 1. In vitro multiplication of Toxoplasma gondii in a liver reticulocyte (day $13 ; a$ ) and in a circulating yolk-sac derived erythrocyte (day $14 ; b$ ) obtained from foetal mice.

Table 1. Multiplication of Toxoplasma gondii in differentiating liver erythroid cells of C57B1/6 foetal mice

\begin{tabular}{|c|c|c|c|c|}
\hline \multirow[b]{2}{*}{$\begin{array}{l}\text { Day of } \\
\text { gestation }\end{array}$} & \multirow[b]{2}{*}{$\begin{array}{l}\text { Incubation } \\
\text { time }(\mathrm{h})\end{array}$} & \multicolumn{3}{|c|}{ Percentage of $T$. gondii multiplied in host cells } \\
\hline & & $\begin{array}{l}\text { Basophilic } \\
\text { erythroblasts }\end{array}$ & $\begin{array}{c}\text { Late } \\
\text { erythroblasts }\end{array}$ & Reticulocytes \\
\hline 12 & $\begin{array}{l}4 \\
8\end{array}$ & $\begin{array}{l}2 \cdot 4(34 \cdot 5)^{*} \\
22 \cdot 7(61 \cdot 2)\end{array}$ & $\begin{array}{r}0(16 \cdot 7) \\
21 \cdot 0(36 \cdot 5)\end{array}$ & $\begin{array}{r}0(37.5) \\
12.9(35.4)\end{array}$ \\
\hline 13 & $\begin{array}{l}4 \\
8\end{array}$ & $\begin{array}{r}1 \cdot 4(32 \cdot 0) \\
22 \cdot 8(49 \cdot 4)\end{array}$ & $\begin{array}{r}3 \cdot 5(18 \cdot 8) \\
16 \cdot 4(41.6)\end{array}$ & $\begin{array}{r}0(19 \cdot 7) \\
12 \cdot 1(28 \cdot 7)\end{array}$ \\
\hline 14 & $\begin{array}{l}4 \\
8\end{array}$ & $\begin{array}{r}1 \cdot 1(62 \cdot 9) \\
33 \cdot 8(79 \cdot 7)\end{array}$ & $\begin{array}{r}3 \cdot 5(47 \cdot 9) \\
31 \cdot 3(48 \cdot 8)\end{array}$ & $\begin{array}{r}0(25 \cdot 0) \\
21 \cdot 3(26 \cdot 7)\end{array}$ \\
\hline
\end{tabular}

* Values in parentheses indicate the percentage of cells containing parasites.

Table 2. Multiplication of Toxoplasma gondii in maturing erythrocytes obtained from the circulation of $\mathrm{C} 57 \mathrm{~B} 1 / 6$ foetal mice

Percentage of $T$. gondii multiplied in host cells

$\begin{array}{cccc}\begin{array}{c}\text { Day of } \\ \text { gestation }\end{array} & \begin{array}{c}\text { Incubation } \\ \text { time }(\mathrm{h})\end{array} & \begin{array}{c}\text { Yolk-sac derived } \\ \text { erythrocytes }\end{array} & \begin{array}{c}\text { Non-nucleated } \\ \text { erythrocytes }\end{array} \\ 11 & 4 & 5 \cdot 2(50 \cdot 5)^{*} & - \\ & 8 & 33 \cdot 0(68 \cdot 0) & - \\ 12 & 24 & 39 \cdot 9(94 \cdot 5) & 0(43 \cdot 0) \\ & 4 & 0(16 \cdot 0) & 11 \cdot 6(50 \cdot 0) \\ 13 & 8 & 8 \cdot 9(34 \cdot 5) & -\dagger \\ & 24 & 34 \cdot 2(20 \cdot 5) & 0(12 \cdot 6) \\ 14 & 4 & 0(23 \cdot 2) & 9 \cdot 1(17 \cdot 2) \\ & 8 & 8 \cdot 7(32 \cdot 3) & 14 \cdot 3(2 \cdot 6) \\ 15 & 24 & 13 \cdot 0(16 \cdot 4) & 0(16 \cdot 4) \\ & 4 & 0(38 \cdot 9) & 6 \cdot 7(17 \cdot 4) \\ & 8 & 5 \cdot 1(33 \cdot 0) & 5 \cdot 9(4 \cdot 3) \\ & 24 & 9 \cdot 1(15 \cdot 4) & 0(18 \cdot 6) \\ 4 & 0(17 \cdot 6) & 2 \cdot 6(16 \cdot 1) \\ & 8 & 0(10 \cdot 7) & 6 \cdot 5(3 \cdot 7)\end{array}$

* Values in parentheses indicate the percentage of cells containing parasites.

$\dagger$ Most erythrocytes degenerated. 


\section{DISCUSSION}

It is well established that erythroid cell differentiation involves sequences of programmed metabolic (Marks \& Kovach, 1966; Lowy, 1977) and structural (Fantoni et al., 1968; Lessin \& Bessis, 1977) changes. DNA and RNA synthesis cease at the late erythroblast stage. Total protein synthesis, predominantly of haemoglobin, stops during the maturation of reticulocyte into erythrocyte. Mitochondria and ribosomes are reduced in number at the late erythroblast stage and at the immature reticulocyte stage, and are eventually lost in erythrocytes. The endoplasmic reticulum is already degenerating in late erythroblasts and is absent from reticulocytes. When we consider these facts along with the present results, it is clear that $T$. gondii multiplication is independent of host cell nuclear DNA or RNA synthesis. since division occurs in non-nucleated foetal reticulocytes. This confirms previous observations (Jones, 1973; Sethi et al., 1973) that $T$. gondii can multiply in fibroblasts artificially enucleated by cytochalasin B. On the other hand, the present study suggests that host cell protein synthesis and/or mitochondrial activities are essential for multiplication. This is supported by the fact that the multiplication rate in the circulating yolk-sac erythrocytes also decreased with maturation, during which a gradual decrease in protein synthesis and in the number of mitochondria have been demonstrated (Chapelle et al., 1969; Kovach et al., 1967). Moreover, protein synthesis had ceased by the 15 th day of gestation (Fantoni et al., 1968), when $T$. gondii multiplication was not detected. This work also suggests that $T$. gondii can multiply in highly specialized cells which are actively synthesizing predominantly one type of protein - haemoglobin - and lacking almost all organelles except mitochondria and ribosomes.

Electron microscopy (Jones et al., 1972) showed that vacuoles containing living, but not dead, Toxoplasma were enveloped with host cell mitochondria and endoplasmic reticulum just after the parasite's entry into the host cells. The mechanism and significance of such envelopment remain unknown. However, the present study suggests an important role for mitochondria but not for endoplasmic reticulum in $T$. gondii multiplication.

It is not yet known how changes such as membrane transport activities affect the rate of $T$. gondii division. Our present findings, however, have clarified some aspects of $T$. gondii parasitism in that all cellular organelles and full functioning of cell metabolism appear to be unnecessary for parasite multiplication. Further biochemical and fine structural studies on multiplication in immature reticulocytes should help to elucidate this.

We thank Dr M. Furusawa, Department of Biology, Faculty of Science, Osaka City University, for his advice during the course of this work.

\section{REFERENCES}

BECKER, Y. (1973). Molecular aspects of the interaction of mammalian cells with obligate microbial parasites and viral agents. Dynamic Aspects of Host-Parasite Relationships 1, 13-44.

Borges, J. S. \& JOHNSON, W. D. (1975). Inhibition of multiplication of Toxoplasma gondii by human monocytes exposed to T-lymphocyte products. Journal of Experimental Medicine 141, 483496.

Chapelle, A., Fantoni, A. \& Marks, P. A. (1969). Differentiation of mammalian somatic cells: DNA and hemoglobin synthesis in fetal mouse yolk sac erythroid cells. Proceedings of the National Academy of Sciences of the United States of America 63, 812-819.

Fantoni, A., Chapelle, A., Rifkind, R. \& Marks,
P. A. (1968). Erythroid cell development in fetal mice: synthetic capacity for different proteins. Journal of Molecular Biology 33, 79-91.

JONES, T. C. (1973). Multiplication of toxoplasmas in enucleate fibroblasts. Proceedings of the Society for Experimental Biology and Medicine 142, 1268-1271.

Jones, T. C. \& HiRsh, J. G. (1972). The interaction between Toxoplasma gondii and mammalian cells. II. The absence of lysosomal fusion with phagocytic vacuoles containing living parasites. Journal of Experimental Medicine 136, 1173-1194.

Jones, T. C., LeN, L. \& Hirsh, J. G. (1975). Assessment in vitro of immunity against Toxoplasma gondii. Journal of Experimental Medicine 141, $466-482$. 
Kovach, J. S., Marks, P. A., Russell, E. S. \& EPLER, H. (1967). Erythroid cell development in fetal mice: ultrastructural characteristics and hemoglobin synthesis. Journal of Molecular Biology 25, 131-142.

Lessin, L. S. \& Bessis, M. (1977). Morphology of the erythron. In Hematology, pp. 103-134. Edited by W. J. Williams, E. Bentler, A. J. Erslev \& R. W. Rundles. New York: McGraw-Hill.

Lowy, B. A. (1977). Synthesis and metabolism of nucleic acids and nucleotides. In Hematology, pp. 142-146. Edited by W. J. Williams, E. Bentler, A. J. Erslev \& R. W. Rundles. New York: McGraw-Hill.

Lund, E., Lycke, E. \& Sourander, P. (1963). Some aspects of cultivation of Toxoplasma gondii in cell cultures. Acta pathologica et microbiologica scandinavica 57, 199-211.

Marks, P. A. \& Kovach, J. S. (1966). Develop- ment of mammalian erythroid cells. Current Topics in Developmental Biology 1, 213-252.

Sethi, K. K., Pelster, B., Piekarski, G. \& Brandis, H. (1973). Multiplication of Toxoplasma gondii in enucleated L cells. Nature New Biology 243, 255-256.

Tanabe, K., Kimata, I., Tabuse, Y., Furusawa, M. \& TAKADA, S. (1978). Toxoplasma gondii: penetration into differentiating Friend erythroleukemia cells. Experimental Parasitology 46, $72-82$.

Tanabe, K., Asai, T., Kimata, I. \& Takada, S. (1979). Penetration of maturating red blood cells by Toxoplasma gondii. Journal of General Microbiology 113, 433-437.

TARbutt, R. G. \& Cole, R. J. (1970). Cell population kinetics of erythroid tissue in the liver of foetal mice. Journal of Embryology and Experimental Morphology 24, 429-446. 